\title{
EVALUATION OF SUNFLOWER CULTIVARS FOR CENTRAL BRAZIL
}

\author{
Willyam Stern Porto ${ }^{1}$; Claudio Guilherme Portela de Carvalho2*; Ronald José Barth Pinto ${ }^{1}$; \\ Marcelo Fernandes de Oliveira²; Ana Cláudia Barneche de Oliveira ${ }^{2}$ \\ ${ }^{1}$ UEM - Depto. de Agronomia, Av. Colombo 5790 - 87020-900 - Maringá, PR - Brasil. \\ ${ }^{2}$ Embrapa Soja, C.P. 231 - 86001-970 - Londrina, PR - Brasil. \\ *Corresponding author <cportela@cnpso.embrapa.br>
}

\begin{abstract}
Despite a large availability of areas suitable for sunflower cropping in Central Brazil, few adapted cultivars are available in the market. The objective of this work was to select sunflower cultivars adapted to this important production region. Experimental data from 2000 to 2004 were obtained by the National Sunflower Trials, coordinated by Embrapa Soja. The evaluated traits were grain and oil yields. Two criteria were used for selection of cultivars: i) the general mean obtained from different environments; ii) partitioning of general mean in favorable and unfavorable environments. Partitioning of the general mean allowed to detect the specific environment indicated for each cultivar. For grain yield, the cultivar Helio 251 presented general indication, Milênio and CF 17 could be indicated for favorable environments and ACA 884, ACA 885 and ACA 872 for the unfavorable ones. For oil yield, CF 13, Milênio, DK 4030, Helio 250 and ACA 872 had general indication; AG 966, GH 12, GV 26043, CF 17 and VDH 93 could be indicated for favorable environments, while VDH 488, Helio 251, ACA 884 and ACA 885 for the unfavorable conditions. In 2002, the partition of the general mean was not carried out. In this year, general mean of cultivars Exp 37, AG 962, GV 26048 and AG 967 were overweight the controls for grain yield and the cultivars AG 962, AG 967, GV 26048, AG 972, BRS 191, Guarani were overweight the controls for oil yield.

Key words: Helianthus annuus, genetic breeding, interaction genotypes $\times$ environments
\end{abstract}

\section{AVALIAÇÃO DE CULTIVARES DE GIRASSOLPARA O BRASIL CENTRAL}

\begin{abstract}
RESUMO: Embora haja uma grande área para o cultivo de girassol no Brasil Central, poucas cultivares adaptadas encontram-se disponíveis no mercado. Esse trabalho teve o objetivo de selecionar cultivares de girassol para essa região de produção de grãos. Os dados foram obtidos da Rede Nacional de Ensaios de Avaliação de Cultivares de Girassol, coordenada pela Embrapa Soja, entre os anos de 2000 e 2004. Os caracteres avaliados foram rendimentos de grão e de óleo. Para a seleção das cultivares, dois critérios foram utilizados: i) a média geral obtida nos diferentes ambientes de teste; ii) a decomposição da média geral em ambientes favoráveis e desfavoráveis. A análise da decomposição da média geral possibilitou detectar para qual tipo de ambiente específico um genótipo poderia ser indicado. Para rendimento de grãos, o genótipo Helio 251 apresentou indicação geral; Milênio e CF 17 foram indicados para os ambientes favoráveis e, para os desfavoráveis, ACA 884, ACA 885 e ACA 872. Para rendimento de óleo, CF 13, Milênio, DK 4030, Helio 250 e ACA 872 tiveram indicação geral; enquanto que AG 966, GH 12, GV 26043, CF 17 e VDH 93 foram indicados para ambientes favoráveis, e VDH 488, Helio 251, ACA 884 e ACA 885 para os desfavoráveis. Em 2002, não foi realizada a decomposição da média geral. Nesse ano, Exp 37, AG 962, GV 26048 e AG 967 destacaram-se para rendimento de grãos e AG 962, AG 967, GV 26048, AG 972, BRS 191, Guarani, para rendimento de óleo.

Palavras-chave: Helianthus annuus, melhoramento genético, interação genótipos $\times$ ambientes
\end{abstract}

\section{INTRODUCTION}

There is an increasing utilization of sunflower in Brazil, due to its use as raw material for silage, oil production and to its potential as a new source of en- ergy from the biological fuel production. Therefore, grown area and grain production increased 60 and $47 \%$, respectively, between 2002/2003 and 2004/2005 (Reunião, 2005). Most of the 82.000 ha cultivated in 2004/2005 were sowed in Central Brazil, following to 
the major summer growing period, mainly in the States of São Paulo (36.7\%), Mato Grosso (17.4\%), Goiás $(10.2 \%)$ and Mato Grosso do Sul (8.8\%) (Reunião, 2005).

On some Brazilian States it is a common agricultural practice the summer double cropping, meaning that the main crop is planted from October to early November, allowing its harvesting by February. Then a second crop follows in February/March, taking advantage of the adequate temperature and rainfall conditions. Sunflower is one of the crops suitable as the second summer crop.

The expansion of the sunflower crop as the second summer crop in Brazil depends on a constant evaluation of new cultivars obtained by the identification of superior materials able to express high yield and acceptable quality in the different regions. Thus the genetic progress of sunflower in Brazil plays an important role to make more feasible the necessary economic returns compared to other summer crops.

Since 1989, the evaluation and selection of hybrids and varieties of sunflower from several companies are being made through of the National Sunflower Trials, coordinated by Embrapa Soja and supported by the contribution of public and private institutions. The aim of this work was to select sunflower cultivars evaluated in the Trial Network carried out between 2000 and 2004 in Central Brazil.

\section{MATERIAL AND METHODS}

Data were used from the National Sunflower Trials, coordinated by Embrapa Soja. Trials were installed from 2000 to 2004 in several locations of the states of Goiás, Mato Grosso, Mato Grosso do Sul, Minas Gerais, São Paulo and Distrito Federal (Table 1).

The cultivars were sown in February/March, in randomized block designs with four replicates. Each plot consisted of four rows $6.0 \mathrm{~m}$ long, spaced from 0.7 to $0.9 \mathrm{~m}$. Only the two central rows were used for data collection. Plants located until $0.5 \mathrm{~m}$ apart from the tip of each central row were also discarded, resulting in a useful area from 7 to $9 \mathrm{~m}^{2}$ per plot, depending on the space adopted. All the recommended cultural practices were observed to allow an optimum plant development.

The evaluated cultivars were simple and triple hybrids and open pollinated varieties developed by the companies ADVANTA, CATI, DOW AgroSciences, Embrapa Soja, La Tijereta and HELIANTHUS DO BRASIL. Commercial hybrids M 734 (DOW AgroSciences) and Agrobel 960 (La Tijereta) were used as controls. In 2001, only the hybrid M734 was used as control. The evaluated traits were grain and oil yields. Cultivar evaluation was carried out during two years in the Final Trials of the First Year of Evalua-

Table 1 - Year of assessment, altitude and geographical coordinates of the National Sunflower Trial locations in the period from 2000 to 2004.

\begin{tabular}{|c|c|c|c|c|c|}
\hline State & Location & Year of Assessment 1 & Latitude & Longitude & Altitude \\
\hline \multirow{6}{*}{ SP } & & & & & $\mathrm{m}$ \\
\hline & Cravinhos & 2002 (FTF) and 2003 (FTS) & $21^{\circ} 20^{\prime} 25^{\prime \prime}$ & $47^{\circ} 43^{\prime} 46^{\prime \prime}$ & 788 \\
\hline & Jaboticabal & 2003 (FTF) & $21^{\circ} 15^{\prime} 17^{\prime \prime}$ & $48^{\circ} 19^{\prime} 20^{\prime \prime}$ & 605 \\
\hline & Jardinópolis & $2001(\mathrm{FTS})$ & $21^{\circ} 01^{\prime} 04^{\prime \prime}$ & $47^{\circ} 45^{\prime} 50^{\prime \prime}$ & 590 \\
\hline & Manduri & 2002, 2003 (FTF) and 2002, 2004 (FTS) & $23^{\circ} 00^{\prime} 12^{\prime \prime}$ & $49^{\circ} 19^{\prime} 19^{\prime \prime}$ & 710 \\
\hline & São Manuel & 2003 (FTS) & $22^{\circ} 43^{\prime} 52^{\prime \prime}$ & $48^{\circ} 34^{\prime} 14^{\prime \prime}$ & 709 \\
\hline \multirow{2}{*}{ MS } & Chapadão do Sul & 2003, 2004 (FTS) & $18^{\circ} 47^{\prime} 39^{\prime \prime}$ & $52^{\circ} 37^{\prime} 22^{\prime \prime}$ & 790 \\
\hline & Dourados & 2003, 2004 (FTS) & $22^{\circ} 13^{\prime} 16^{\prime \prime}$ & $54^{\circ} 48^{\prime} 20^{\prime \prime}$ & 430 \\
\hline \multirow{5}{*}{ MT } & Campo Novo do Parecis & 2003 (FTF) and 2001, 2003, 2004 (FTS) & $13^{\circ} 40^{\prime} 31^{\prime \prime}$ & $57^{\circ} 53^{\prime} 31^{\prime \prime}$ & 572 \\
\hline & Jaciara & 2001 (FTS) & $15^{\circ} 57^{\prime} 55^{\prime \prime}$ & $54^{\circ} 58^{\prime} 06^{\prime \prime}$ & 367 \\
\hline & Juscimeira & 2002 (FTS) & $16^{\circ} 03^{\prime} 02^{\prime \prime}$ & $54^{\circ} 53^{\prime} 04^{\prime \prime}$ & 251 \\
\hline & Nova Mutum & $2003(\mathrm{FTF})$ & $13^{\circ} 49^{\prime} 44^{\prime \prime}$ & $56^{\circ} 04^{\prime} 56^{\prime \prime}$ & 460 \\
\hline & Primavera do Leste & $2000(\mathrm{FTF})$ & $15^{\circ} 33^{\prime} 32^{\prime \prime}$ & $54^{\circ} 17^{\prime} 46^{\prime \prime}$ & 465 \\
\hline \multirow{2}{*}{ GO } & Jataí & $2002($ FTF) and 2002, 2003 (FTS) & $17^{\circ} 52^{\prime} 53^{\prime \prime}$ & $51^{\circ} 42^{\prime} 52^{\prime \prime}$ & 708 \\
\hline & Rio Verde & $2001(\mathrm{FTS})$ & $17^{\circ} 46^{\prime} 03^{\prime \prime}$ & $51^{\circ} 01^{\prime} 50^{\prime \prime}$ & 836 \\
\hline MG & Uberlândia & 2001 (FTF) and 2001 (FTS) & $18^{\circ} 55^{\prime} 23^{\prime \prime}$ & $48^{\circ} 17^{\prime} 19^{\prime \prime}$ & 863 \\
\hline $\mathrm{DF}$ & Planaltina & 2002, 2003, 2004 (FTS) & $15^{\circ} 35^{\prime} 30^{\prime \prime}$ & $47^{\circ} 42^{\prime} 30^{\prime \prime}$ & 1007 \\
\hline
\end{tabular}

${ }^{1}$ FTF - Evaluations made in Final Trials of the First Year of Evaluation and FTS - Evaluations made in Final Trials of the Second Year of Evaluation. 
tion (FTF) and in Final Trials of the Second Year of Evaluation (FTS) (Table 1). From 2001 to 2004, eleven, fifteen, ten and six cultivars were evaluated. Evaluations made in 2001, include the experimental data obtained from the Final Trials of First Year of Evaluation 2000 and from the Final Trials of Second Year of Evaluation 2001, with similar procedure for other years of evaluation.

The analysis of variance was performed on grain and oil yields for each environment (location and year). As the locations of the trials included in the FTF were not exactly the same ones as those chosen for the FTS, a joint analysis of environment for each group of cultivars was carried out. For this, a test to verify the homogeneity of residual variances was applied. In this test, variances were considered as homogeneous when the ratio between the larger and the smaller residual mean square was smaller than 7 (Pimentel Gomes, 1985). Moreover, trials with coefficients of variation higher than 20\% (Pimentel Gomes, 1985) and experiments with major problems (birds attacks, drought and serious incidence of plant diseases, like Alternaria) were not included in the joint analysis of variance.

Two criteria were used for selection of cultivars: i) the general mean obtained from different environments; and ii) partitioning of general mean in favorable and unfavorable environments. It was considered favorable environment those with superior general mean and unfavorable one those with inferior general mean (Verma et al., 1978).

In the analysis of the general mean, Duncan test $(P<0.05)$ was performed to verify significance of differences among cultivars, as well as the comparison of means among each evaluated cultivar and the controls. The favorable and unfavorable environment means of each cultivar were compared with the control mean in each environment, according to the IDMG method (Indication Method - Partitioning of
General Mean) (Porto et al., 2007). When the mean of a certain cultivar is higher than the control mean in favorable but not in unfavorable environments, this cultivar is regarded oneself as fitted for favorable environments, and vice versa. On the other hand, if a certain cultivar is superior in both environments, its indication is general. The partitioning of the general mean was not calculated when the number of favorable and unfavorable environments was equal or less than three. The statistical analyses were performed with the software Genes (Cruz, 2001).

\section{RESULTS AND DISCUSSION}

The interaction cultivars $\times$ environments was significant in the joint analysis of variance, indicating a different performance of cultivars over the evaluated environments, and pointing out the importance of studies of yield components in specific environments (Table 2 ). The presence of $G \times E$ interaction in sunflower yield tests has also been reported by Embrapa (1996; 1997; 1998; 1999; 2000); Lu'Quez et al. (2002) and De la Vega \& Chapman (2006). The experimental accuracy was satisfactory according the classification of Pimentel Gomes (1985), since the coefficients of variation $(\mathrm{CV})$ were comprised between $11.83 \%$ and $14.33 \%$ for grain yield and between $12.23 \%$ and $14.51 \%$ for oil yield. General means for grain yield over year were remarkable superior to the approximately $1500 \mathrm{~kg} \mathrm{ha}^{-1}$, observed in Brazilian commercial agriculture, according to data from CONAB (2005).

In spite of the acceptable values of $\mathrm{CV}$, differences among cultivars were detected by Duncan test $(P<0.05)$ only when a large difference among their means was observed for both evaluated traits (Table 3), as reported by Embrapa (1996; 1997; 1998; 1999; 2000). Therefore selection of sunflower cultivars was made based on the difference between their performance and the mean of controls, so that selected ma-

Table 2 - Joint analyses of variance for grain and oil yields $\left(\mathrm{kg} \mathrm{ha}^{-1}\right)$ of sunflower cultivars evaluated in the National Sunflower Trials, coordinated by Embrapa, in the period from 2000 to 2004.

\begin{tabular}{|c|c|c|c|c|c|c|}
\hline \multirow{3}{*}{ Year $^{1}$} & \multicolumn{6}{|c|}{ Yield $\left(\mathrm{kg} \mathrm{ha}^{-1}\right)$} \\
\hline & \multicolumn{3}{|l|}{ Grain } & \multicolumn{3}{|l|}{ Oil } \\
\hline & $\mathrm{QMGA}^{2}$ & $\mathrm{CV}^{3}$ & Mean $^{4}$ & QMGA & $\mathrm{CV}$ & Mean \\
\hline 2001 & $211,209.45 * *$ & 12.44 & 1863.71 & $51,440.64 * *$ & 13.41 & 819.37 \\
\hline 2002 & $371,927.69 * *$ & 11.83 & 1702.46 & $50,324.94 * *$ & 12.23 & 662.92 \\
\hline 2003 & $326,407.84 * *$ & 12.18 & 1901.23 & $57,947.50 * *$ & 13.75 & 751.02 \\
\hline 2004 & $178,296.76^{* *}$ & 14.33 & 2054.87 & $34,646.46 * *$ & 14.51 & 824.28 \\
\hline
\end{tabular}

**Significant at $1 \%$ for $\mathrm{F}$ test. ${ }^{1}$ Evaluations made in 2001 (sowing date on February/March) include the experimental data obtained in the Final Trials of First Year of Evaluation 2000 and Final Trials of Second Year of Evaluation 2001, with similar procedure for other years of evaluation. ${ }^{2} \mathrm{QMGA}$ : Mean square for the interaction cultivars $\times$ environments. ${ }^{3} \mathrm{CV}$ : Coefficient of variation $(\%)$. ${ }^{4} \mathrm{General}$ mean, in $\mathrm{kg} \mathrm{ha}^{-1}$. 
Table 3 - Means of sunflower cultivars evaluated in the National Sunflower Trials, coordinated by Embrapa, between 2000 and 2004, for grain and oil yields.

\begin{tabular}{|c|c|c|c|c|c|c|c|}
\hline \multicolumn{8}{|c|}{ Grain yield $\left(\mathrm{kg} \mathrm{ha}^{-1}\right)$} \\
\hline \multicolumn{2}{|c|}{$2001^{1}$} & \multicolumn{2}{|c|}{2002} & \multicolumn{2}{|c|}{2003} & \multicolumn{2}{|l|}{2004} \\
\hline Cultivar $^{2}$ & Mean $^{3}$ & Cultivar & Mean & Cultivar & Mean & Cultivar & Mean \\
\hline M $734(\mathrm{H})$ & 2046.46 a & Exp $37(\mathrm{H})$ & $1981.78 \mathrm{a}$ & M $734(\mathrm{H})$ & $2152.36 \mathrm{a}$ & M $734(\mathrm{H})$ & $2381.04 \mathrm{a}$ \\
\hline MILENIO (H) & $2028.32 \mathrm{a}$ & AGB $962(\mathrm{H})$ & $1968.56 \mathrm{ab}$ & Helio $251(\mathrm{H})$ & $2043.74 \mathrm{ab}$ & AG $960(\mathrm{H})$ & $2197.59 \mathrm{~b}$ \\
\hline CF $17(\mathrm{H})$ & $1950.65 \mathrm{a}$ & GV $26048(\mathrm{H})$ & $1865.03 \mathrm{abc}$ & ACA $884(\mathrm{H})$ & $1988.37 \mathrm{ab}$ & V $10034(\mathrm{H})$ & 2070.32 c \\
\hline CF $13(\mathrm{H})$ & $1896.36 \mathrm{a}$ & AGB $967(\mathrm{H})$ & $1725.45 \mathrm{abcd}$ & ACA $872(\mathrm{H})$ & $1951.09 \mathrm{ab}$ & Helio $358(\mathrm{H})$ & $1986.26 \mathrm{~d}$ \\
\hline DK $4030(\mathrm{H})$ & $1885.57 \mathrm{a}$ & M 734 (H) & 1713.49 abcd & Helio $250(\mathrm{H})$ & $1919.29 \mathrm{ab}$ & Multissol (V) & $1938.98 \mathrm{~d}$ \\
\hline GH $12(\mathrm{H})$ & $1881.52 \mathrm{a}$ & Guarani (H) & $1685.43 \mathrm{abcd}$ & ACA $885(\mathrm{H})$ & $1911.18 \mathrm{ab}$ & Embrapa $122(\mathrm{~V})$ & $1755.00 \mathrm{e}$ \\
\hline VDH $93(\mathrm{H})$ & $1867.09 \mathrm{a}$ & AG $960(\mathrm{H})$ & $1681.96 \mathrm{abcd}$ & V $80198(\mathrm{H})$ & $1855.87 \mathrm{ab}$ & - & - \\
\hline AG $966(\mathrm{H})$ & $1859.40 \mathrm{a}$ & Exp $36(\mathrm{H})$ & $1670.70 \mathrm{bcd}$ & AG $960(\mathrm{H})$ & $1819.18 \mathrm{ab}$ & - & - \\
\hline GV $26043(\mathrm{H})$ & $1852.70 \mathrm{a}$ & AGB $972(\mathrm{H})$ & $1663.50 \mathrm{~cd}$ & V $90064(\mathrm{H})$ & $1738.43 \mathrm{ab}$ & - & - \\
\hline VDH $488(\mathrm{H})$ & $1831.48 \mathrm{a}$ & IAC Uruguai (V) & $1641.30 \mathrm{~cd}$ & Catissol (V) & $1632.81 \mathrm{~b}$ & - & - \\
\hline HT $3(\mathrm{H})$ & $1401.28 \mathrm{~b}$ & BRS $191(\mathrm{H})$ & $1610.90 \mathrm{~cd}$ & - & - & - & - \\
\hline- & - & Exp $38(\mathrm{H})$ & $1609.78 \mathrm{~cd}$ & - & - & - & - \\
\hline- & - & $\operatorname{Exp} 33(\mathrm{H})$ & $1584.63 \mathrm{~cd}$ & - & - & - & - \\
\hline- & - & Catissol (V) & $1431.89 \mathrm{~d}$ & - & - & - & - \\
\hline General mean & 1863.71 & General mean & 1702.45 & General mean 1 & 901.23 & General mean & 2054.86 \\
\hline Control mean & 2046.46 & Control mean & 1697.72 & Control mean 1 & 985.77 & Control mean & 2289.31 \\
\hline \multicolumn{8}{|c|}{ Oil yield $\left(\mathrm{kg} \mathrm{ha}^{-1}\right)$} \\
\hline 2001 & & 2002 & & 2003 & & 2004 & \\
\hline Cultivar & Mean & Cultivar & Mean & Cultivar & Mean & Cultivar & Mean \\
\hline CF $13(\mathrm{H})$ & $901.37 \mathrm{a}$ & AGB $962(\mathrm{H})$ & $821.89 \mathrm{a}$ & Helio $250(\mathrm{H})$ & $827.41 \mathrm{a}$ & AG $960(\mathrm{H})$ & $930.41 \mathrm{a}$ \\
\hline MILENIO (H) & $894.42 \mathrm{a}$ & AGB $967(\mathrm{H})$ & $804.60 \mathrm{ab}$ & M $734(\mathrm{H})$ & $808.92 \mathrm{a}$ & M $734(\mathrm{H})$ & $903.26 \mathrm{ab}$ \\
\hline DK $4030(\mathrm{H})$ & $864.60 \mathrm{a}$ & GV $26048(\mathrm{H})$ & $720.32 \mathrm{abc}$ & ACA $872(\mathrm{H})$ & $791.46 \mathrm{a}$ & Helio $358(\mathrm{H})$ & $884.50 \mathrm{~b}$ \\
\hline AG $966(\mathrm{H})$ & $859.78 \mathrm{a}$ & AGB $972(\mathrm{H})$ & $711.24 \mathrm{abcd}$ & Helio $251(\mathrm{H})$ & $776.45 \mathrm{a}$ & V $10034(\mathrm{H})$ & $796.06 \mathrm{c}$ \\
\hline GH $12(\mathrm{H})$ & $855.21 \mathrm{a}$ & AG $960(\mathrm{H})$ & $709.09 \mathrm{abcd}$ & ACA $884(\mathrm{H})$ & 758.76 a & Multissol (V) & $734.78 \mathrm{~d}$ \\
\hline M $734(\mathrm{H})$ & $821.29 \mathrm{a}$ & BRS $191(\mathrm{H})$ & 704.37 abcde & ACA $885(\mathrm{H})$ & $747.38 \mathrm{a}$ & Embrapa $122(\mathrm{~V})$ & 696.65 e \\
\hline VDH $488(\mathrm{H})$ & $819.91 \mathrm{a}$ & Guarani (H) & 696.70 abcde & V $80198(\mathrm{H})$ & $745.37 \mathrm{a}$ & - & - \\
\hline GV $26043(\mathrm{H})$ & $812.00 \mathrm{a}$ & M $734(\mathrm{H})$ & 659.69 bcde & AG $960(\mathrm{H})$ & $736.53 \mathrm{a}$ & - & - \\
\hline CF $17(\mathrm{H})$ & $791.02 \mathrm{a}$ & $\operatorname{Exp} 33(\mathrm{H})$ & $621.56 \mathrm{cdef}$ & V $90064(\mathrm{H})$ & $685.59 \mathrm{a}$ & - & - \\
\hline VDH $93(\mathrm{H})$ & $779.51 \mathrm{a}$ & Exp $36(\mathrm{H})$ & $615.11 \mathrm{cdef}$ & Catissol (V) & $632.32 \mathrm{a}$ & - & - \\
\hline HT $3(\mathrm{H})$ & $613.99 \mathrm{~b}$ & Exp $38(\mathrm{H})$ & $611.63 \mathrm{cdef}$ & - & - & - & - \\
\hline- & - & Catissol (V) & $555.49 \mathrm{def}$ & - & - & - & - \\
\hline- & - & IAC Uruguai (V) & 549.58 ef & - & - & - & - \\
\hline- & - & Exp $37(\mathrm{H})$ & $499.61 \mathrm{f}$ & - & - & - & - \\
\hline General mean & 819.37 & General mean & 662.92 & General mean & 751.02 & General mean & 824.28 \\
\hline Control mean & 821.29 & Control mean & 684.39 & Control mean & 772.72 & Control mean & 916.83 \\
\hline
\end{tabular}

${ }^{1}$ Evaluations made in 2001 (sowing date on February/March) include the experimental data obtained in the Final Trials of First Year of Evaluation 2000 and Final Trials of Second Year of Evaluation 2001, with similar procedure for others years of evaluation. ${ }^{2} \mathrm{H}=$ hybrid and $\mathrm{V}=$ open pollinated variety. ${ }^{3}$ Means followed by the same letter did not differ at the Duncan test $(P \leq 0.05)$.

terials were those with means higher than that of controls. This criterion is rigorous whereas it causes a greater strictness in discriminating cultivars in comparison with selection based on results from the Duncan test, therefore it reduces the number of selected cultivars. Despite this constraint, this criterion has been used by the Brazilian Ministry of Agriculture,
Livestock and Food Supply (MAPA) for the registration of new soybean, wheat and bean cultivars. No criterion was established for sunflower up to now.

In the period of 2000-2004, the cultivars that presented a general mean higher than the controls for grain yield were Exp 37, AG 962, GV 26048, AG 967, Helio 251 and ACA 884. For oil yield, the best culti- 
vars were CF 13, Milênio, DK 4030, AG 966, GH 12, AG 962, AG 967, GV 26048, AG 972, BRS 191, Guarani, Helio 250, Helio 251 and ACA 872. Only cultivars AG 962, AG 967, GV 26048 and Helio 251 presented a better performance for the two evaluated components of yield (Table 3). Thus, cultivars not always had a good performance for both traits. The use of cultivars with outstanding performance in only one of the evaluated components depends on the farmer pref- erence at the time of choice a hybrid variety and also must be based on the effective politics of trade by the sunflower industry. Currently, industries grant a bonus for cultivars whose oil content is above $40 \%$. When the bonus is paid, farmers prefer hybrids with higher oil content then those with higher grain yield.

From 2000 to 2004, the National Sunflower Trials evaluated simple and triple hybrids and open pollinated varieties. In this period, no open pollinated va-

Table 4 - Partition of means of sunflower cultivars evaluated in favorable and unfavorable environments for grain and oil yields, from experiments carried out from 2000 to 2004.

\begin{tabular}{|c|c|c|c|c|c|c|c|c|c|c|c|}
\hline \multicolumn{12}{|c|}{ Grain yield $\left(\mathrm{kg} \mathrm{ha}^{-1}\right)$} \\
\hline \multicolumn{4}{|c|}{$2001^{1}$} & \multicolumn{4}{|c|}{2003} & \multicolumn{4}{|c|}{2004} \\
\hline Cultivar $^{2}$ & $\mathrm{GM}^{3}$ & $\mathrm{UM}^{4}$ & $\mathrm{FM}^{5}$ & Cultivar & GM & $\mathrm{UM}$ & FM & Cultivar & GM & UM & FM \\
\hline M $734(\mathrm{H})$ & 2046.46 & 1721.82 & 2479.32 & M $734(\mathrm{H})$ & 2152.36 & 1766.16 & 2538.55 & M $734(\mathrm{H})$ & 2381.04 & 1880.14 & 3007.17 \\
\hline MILENIO (H) & 2028.32 & 1572.94 & 2635.49 & Helio $251(\mathrm{H})$ & 2043.74 & 1691.40 & 2396.07 & AG $960(\mathrm{H})$ & 2197.59 & 1860.04 & 2619.54 \\
\hline CF $17(\mathrm{H})$ & 1950.65 & 1453.43 & 2613.61 & ACA $884(\mathrm{H})$ & 1988.37 & 1727.43 & 2249.31 & V $10034(\mathrm{H})$ & 2070.32 & 1811.65 & 2393.66 \\
\hline CF $13(\mathrm{H})$ & 1896.36 & 1525.70 & 2390.57 & ACA $872(\mathrm{H})$ & 1951.09 & 1667.56 & 2234.64 & Helio $358(\mathrm{H})$ & 1986.26 & 1641.19 & 2417.60 \\
\hline DK $4030(\mathrm{H})$ & 1885.57 & 1590.35 & 2279.19 & Helio $250(\mathrm{H})$ & 1919.29 & 1569.24 & 2269.34 & Multissol (V) & 1938.98 & 1584.40 & 2382.22 \\
\hline GH $12(\mathrm{H})$ & 1881.52 & 1441.79 & 2467.82 & ACA $885(\mathrm{H})$ & 1911.18 & 1703.99 & 2118.38 & EMB $122(V)$ & 1755.00 & 1471.26 & 2109.69 \\
\hline VDH 93 (H) & 1867.09 & 1485.54 & 2375.83 & V $80198(H)$ & 1855.87 & 1567.44 & 2144.29 & - & - & - & - \\
\hline AG $966(\mathrm{H})$ & 1859.40 & 1500.46 & 2338.00 & AG $960(\mathrm{H})$ & 1819.18 & 1447.22 & 2191.15 & - & - & - & - \\
\hline GV $26043(\mathrm{H})$ & 1852.70 & 1516.78 & 2300.60 & V $90064(\mathrm{H})$ & 1738.43 & 1377.21 & 2099.65 & - & - & - & - \\
\hline VDH $488(\mathrm{H})$ & 1831.48 & 1582.96 & 2162.84 & Catissol (V) & 1632.81 & 1425.58 & 1840.04 & - & - & - & - \\
\hline HT $3(\mathrm{H})$ & 1401.28 & 1144.01 & 1744.32 & - & . & - & - & - & - & - & - \\
\hline General mean & 1863.71 & 1503.25 & 2344.32 & General mean & 1901.23 & 1594.32 & 2208.14 & General mean & 2054.85 & 1708.112 & 2488.31 \\
\hline Control mean & 2046.46 & 1721.82 & 2479.32 & Control mean & 1985.77 & 1606.69 & 2364.85 & Control mean & 2289.31 & 1870.092 & 2813.35 \\
\hline \multicolumn{12}{|c|}{ Oil yield $\left(\mathrm{kg} \mathrm{ha}^{-1}\right)$} \\
\hline \multicolumn{4}{|c|}{2001} & \multicolumn{4}{|c|}{2003} & \multicolumn{4}{|c|}{2004} \\
\hline Cultivar & GM & UM & FM & Cultivar & GM & UM & FM & Cultivar & GM & UM & FM \\
\hline CF $13(\mathrm{H})$ & 901.37 & 724.20 & 1137.60 & Helio $250(\mathrm{H})$ & 827.41 & 679.54 & 1049.23 & AG $960(\mathrm{H})$ & 930.41 & 786.92 & 1217.40 \\
\hline MILENIO (H) & 894.42 & 719.29 & 1127.92 & M $734(\mathrm{H})$ & 808.92 & 682.11 & 999.13 & M $734(\mathrm{H})$ & 903.26 & 747.88 & 1214.01 \\
\hline DK $4030(\mathrm{H})$ & 864.60 & 747.33 & 1020.95 & ACA $872(\mathrm{H})$ & 791.46 & 662.00 & 985.66 & Helio $358(\mathrm{H})$ & 884.50 & 723.46 & 1206.57 \\
\hline AG $966(\mathrm{H})$ & 859.78 & 682.66 & 1095.94 & Helio $251(\mathrm{H})$ & 776.45 & 656.92 & 955.76 & V $10034(\mathrm{H})$ & 796.06 & 650.99 & 1086.20 \\
\hline GH $12(\mathrm{H})$ & 855.21 & 667.35 & 1105.69 & ACA $884(\mathrm{H})$ & 758.76 & 683.31 & 871.93 & Multissol (V) & 734.78 & 613.44 & 977.44 \\
\hline M $734(\mathrm{H})$ & 821.29 & 716.42 & 961.13 & ACA $885(\mathrm{H})$ & 747.38 & 668.51 & 865.68 & EMB $122(\mathrm{~V})$ & 696.65 & 598.31 & 893.33 \\
\hline VDH $488(\mathrm{H})$ & 819.91 & 725.72 & 945.50 & V $80198(\mathrm{H})$ & 745.37 & 628.10 & 921.27 & - & - & - & - \\
\hline GV $26043(\mathrm{H})$ & 812.00 & 676.40 & 992.80 & AG $960(\mathrm{H})$ & 736.53 & 601.75 & 938.69 & - & - & - & - \\
\hline CF $17(\mathrm{H})$ & 791.02 & 602.74 & 1042.05 & V $90064(H)$ & 685.59 & 554.92 & 881.60 & - & - & - & - \\
\hline VDH $93(\mathrm{H})$ & 779.51 & 622.85 & 988.39 & Catissol (V) & 632.32 & 510.63 & 814.86 & - & - & - & - \\
\hline HT $3(\mathrm{H})$ & 613.99 & 496.92 & 770.08 & - & - & - & - & - & - & - & - \\
\hline General mean & 819.37 & 671.08 & 1017.09 & General mean & 751.01 & 632.77 & 928.38 & General mean & 824.27 & 686.83 & 1099.15 \\
\hline Control mean & 821.29 & 716.42 & 961.13 & Control mean & 772.72 & 641.93 & 968.91 & Control mean & 916.83 & 767.40 & 1215.70 \\
\hline
\end{tabular}

${ }^{1}$ Evaluations made in 2001 include the experimental data obtained in the Final Trials of First Year of Evaluation 2000 and Final Trials of Second Year of Evaluation 2001, in the same way, for many years of evaluation. Partition of the general mean was not performed in 2002, because in those experiments the number of favorable environments was less than four. ${ }^{2} \mathrm{H}=$ hybrid and $\mathrm{V}=$ open pollinated variety. ${ }^{3} \mathrm{GM}=$ general mean. ${ }^{4} \mathrm{UM}=$ average in unfavorable environments. ${ }^{5} \mathrm{FM}=$ average in favorable environments. 
riety was greater than the control mean (Table 3). These values varied from 3.3\% (IAC Uruguai in 2002) to $23.3 \%$ (Embrapa 122 in 2004) for grain yield and from 18.2\% (Catissol in 2004) to 24.0\% (Embrapa 122 in 2004). Nevertheless, the use of open pollinated varieties may be meaningful for the farmholders, due to low seed price and less environmental risk (water deficit), when sunflower crop is sown on February/March.

For selection of sunflower cultivars normally used general means of grain and oil content from different environments (Embrapa, 1996; 1997; 1998; 1999; 2000). Although it should be taken into account the specific adaptation of the favorable and unfavorable environments (Ramalho et al., 1993; Cruz \& Regazzi, 1994; Lu'Quez et al., 2002; De la Vega \& Chapman, 2006). In this study, the method of the IDMG allowed to detecting cultivars for a specific environment (Table 4). For grain yield, only the cultivar Helio 251 had general indication. Milênio and CF 17 would be indicated for favorable environments and ACA 884, ACA 885 and ACA 872 for the unfavorable ones. For oil yield, CF 13, Milênio, DK 4030, Helio 250 and ACA 872 had general indication; AG 966, GH 12, GV 26043, CF 17 and VDH 93 would be indicated for favorable environments, while VDH 488, Helio 251, ACA 884 and ACA 885 for the unfavorable conditions. The IDMG analysis was not performed in 2002, because in those experiments the number of favorable environments was less than four. Some cultivars that did not present a superior average in comparison with the controls had good performance in specific environments. For instance, cultivar ACA 885 was indicated for unfavorable environments for grain and oil yields (Table 4), although its general average was smaller than one of the controls.

\section{CONCLUSIONS}

For grain yield, the cultivar Helio 251 presents general indication, Milênio and CF 17 would be recommended for favorable environments and ACA 884, ACA 885 and ACA 872 would be indicated for the unfavorable environments when sowed on February/ March. For oil yield, CF 13, Milênio, DK 4030, Helio 250 and ACA 872 present general indication; AG 966, GH 12, GV 26043, CF 17 and VDH 93 would be indicated for favorable environments, while VDH 488, Helio 251, ACA 884 and ACA 885 would be indicated for the unfavorable ones, when sowed at the same date.

\section{REFERENCES}

COMPANHIA NACIONAL DE ABASTECIMENTO - CONAB. Acompanhamento da safra 2004/2005. Brasília: CONAB. Available at http://www.conab.gov.br. Accessed 15 Nov. 2005.

CRUZ, C.D. Programa Genes: versão Windows; aplicativo computacional em genética e estatística. Viçosa: UFV, Imprensa Universitária, 2001. 648p.

CRUZ, C.D.; REGAZZI, A.J. Modelos biométricos aplicados ao melhoramento genético. Viçosa: UFV, Imprensa Universitária, 1994. 390p.

DE LA VEGA, A.J.; CHAPMAN, S.C. Defining sunflower selection strategies for a highly heterogeneous target population of environments. Crop Science, v.46, p.136-144, 2006.

EMPRESA BRASILEIRA DE PESQUISA AGROPECUÁRIA EMBRAPA. Informes da avaliação de genótipos de girassol da Rede Oficial, 1995/1996 e 1996. Londrina: EMBRAPA, CNPSo, 1996. 85p. (Documentos, 98).

EMPRESA BRASILEIRA DE PESQUISA AGROPECUÁRIA EMBRAPA. Informes da avaliação de genótipos de girassol da Rede Oficial, 1996/1997 e 1997. Londrina: EMBRAPA, CNPSo, 1997. 116p. (Documentos, 110).

EMPRESA BRASILEIRA DE PESQUISA AGROPECUÁRIA EMBRAPA. Informes da avaliação de genótipos de girassol da Rede Oficial, 1997/1998 e 1998. Londrina: EMBRAPA, CNPSo, 1998. 92p. (Documentos, 122).

EMPRESA BRASILEIRA DE PESQUISA AGROPECUÁRIA EMBRAPA. Informes da avaliação de genótipos de girassol da Rede Oficial, 1998/1999 e 1999. Londrina: Embrapa Soja, 1999. 99p. (Documentos, 122).

EMPRESA BRASILEIRA DE PESQUISA AGROPECUÁRIA EMBRAPA. Informes da avaliação de genótipos de girassol, 1999/2000 e 2000. Londrina: Embrapa Soja, 2000. 92p. (Documentos, 151).

LU'QUEZ, J.E.; AGUIRREZÁBAL, L.A.N.; AGÜERO, M.E.; PEREYRA, V.R. Stability and adaptability of cultivars in nonbalanced yield trials. Comparison of methods for selecting 'high oleic' sunflower hybrids for grain yield and quality. Journal of Agronomy and Crop Science, v.188, p.225-234, 2002.

PIMENTEL GOMES, F. Curso de estatística experimental. 13.ed. São Paulo: USP-ESALQ, 1985. 468p.

PORTO, W.S.; CARVALHO, C.G.P.; PINTO, R.J.B. Adaptabilidade e estabilidade como critérios para seleção de genótipos de girassol. Pesquisa Agropecuária Brasileira, v.42, p.491-499, 2007.

RAMALHO, M.A.P.; SANTOS, J.B.; ZIMMERMANN, M.J.O. Genética quantitativa em plantas autógamas; aplicações ao melhoramento do feijoeiro. Goiânia: UFG, 1993. 271p.

REUNIÃO NACIONAL DE PESQUISA DE GIRASSOL, 16. , Londrina, 2005. Ata... Londrina: Embrapa Soja, 2005. 111p.

VERMA, M.M.; CHAHAL, G.S.; MURTY, B.R. Limitations of conventional regression analysis: a proposed modification. Theoretical and Applied Genetics, v.53, p.89-91, 1978

Received December 19, 2006

Accepted September 03, 2007 